\title{
Wyrok Sądu Metropolitalnego w Katowicach (c. Sobański) z 17.09.1998 r. z tytułu wykluczenia potomstwa
}

Ius Matrimoniale 4 (10), 285-289

1999

Artykuł został zdigitalizowany i opracowany do udostępnienia w internecie przez Muzeum Historii Polski w ramach prac podejmowanych na rzecz zapewnienia otwartego, powszechnego i trwałego dostępu do polskiego dorobku naukowego i kulturalnego. Artykuł jest umieszczony w kolekcji cyfrowej bazhum.muzhp.pl, gromadzącej zawartość polskich czasopism humanistycznych i społecznych.

Tekst jest udostępniony do wykorzystania w ramach dozwolonego użytku. 


\section{Wyrok Sądu Metropolitalnego w Katowicach (c.Sobański) z 17.9.1998 r. z tytuku wykluczenia potomstwa.}

T.P. i M.M. zawarli małżeństwo 9.4.1961. Ważność tego małżeństwa zaskarżył T.P. 1.12.1966 z tytułu przymusu wywartego na powoda oraz $z$ tytułu wykluczenia potomstwa przez pozwana. Sąd orzekł 6.11.1968, iż nie udowodniono małżeństwa $z$ żadnego $z$ rozpatrywanych tytułów. Wskutek apelacji powoda wniesionej dopiero 28.11.1980 sprawa znalazła się w sądzie drugiej instancji. Trybunał II instancji 14.8.1982 zatwierdził wyrok negatywny $z$ tytułu przymusu, uchylił natomiast wyrok $z$ tytułu wykluczenia potomstwa przez pozwaną orzekając, iż udowodniono nieważność malżeństwa $z$ tego tytułu. Zgodnie z obowiązującymi wówczas normami prawa obrońca węzła małżeńskiego wniósł apelację do III instancji. Sąd ten zwrócił się do stron z zapytaniem, czy podtrzymuja obydwa tytuły nieważności. Otrzymawszy odpowiedź pozytywną (mimo braku nowych dowodów odnośnie do przymusu) Trybunał III instancji zadecydował orzekać z obydwu tytułów. Dnia 1.6.1983 Trybunał ten postanowił „tytuł nieważności małżeństwa przymusu i bojaźni po stronie powoda oraz wykluczenie potomstwa przez pozwaną uznać za nieudowodniony", co równało się uchyleniu wyroku Trybunału II instancji w części orzekającej nieważność małżeństwa. Pismem z 16.2.1998 powód zwrócił się do Najwyższego Trybunału Sygnatury Apostolskiej o wyznaczenie - o ile to możliwe - Sądu Metropolitalnego w Katowicach do rozpatrzenia sprawy w kolejnej instancji. Dekretem z 6.3.1998 (Prot.N.28739/98 C.P.) Trybunał Sygnatury Apostolskiej wyznaczył Sąd Metropolitalny w Katowicach do osądzenia w czwartej instancji, czy są nowe i poważne dowody i argumenty uzasadniajace kolejne rozpatrzenie sprawy. Sąd Metropolitalny na sesji 14.5.1998 odpowiedział twierdząco na pytanie, czy należy dopuścić sprawę do osądzenia w czwartej instancji. Powód przedstawił czworo świadków, których przesłuchano. Pozwana nie odpowiedziała na pisma Sądu. Obecnie Sąd ma odpowiedzieć na pytanie: czy udowodniono nieważność małżeństwa z tytułu wykluczenia potomstwa przez pozwana. 


\section{PRAWNY I FAKTYCZNY STAN SPRAWY:}

1. Orzeczenie Trybunału I instancji, iż nie udowodniono wykluczenia potomstwa przez pozwana, opiera się przede wszystkim na jej zeznaniach. Pozwana przyznaje, iż mówiła powodowi, że nie chce i nie będzie miała dziecka, ale nie rozumiała tego w ten sposób, ,że absolutnie nigdy nie będzie miała dziecka". Ewentualne wypowiedzi wobec innych osób (np. koleżanki A.B.) też należało rozumieć w tym sensie, że na razie nie będzie dzieci. Wychodząc za mąż pozwana byla w ciąży, a skoro powód zaproponował małżeństwo, zdecydowała się urodzić dziecko, nie zastanawiała się nad tym, czy będą dalsze dzieci. Niedługo po ślubie poroniła, czego jednak nie spowodowała celowo, bo „była zdecydowana urodzić dziecko". Zanim jeszcze zapadła decyzja o zawarciu małżeństwa, zażywała chininy, bo wydawało się jej, że „w ten sposób nastąpi przerwanie ciąży". Nie miało to jednak faktycznego wpływu na poronienie, które było - wedle lekarza - raczej wynikiem jej ,naturalnej skłonności" powodowej budową. Po ślubie dwukrotnie dokonała przerwania. ciąży, bo nie chciała ,ryzykować", bojąc się, że wobec jej skłonności do poronień, byłoby niebezpiecznie dla jej życia, gdyby poronienie nastąpito przy „wysoko zaawansowanej” ciąży. Także jednak wtedy, gdy przerywała ciąże, nie była zdecydowana, by nigdy nie mieć dziecka. Trybunał I instancji uznał zeznania pozwanej za logiczne, ocenił je jako zaprzeczenie wykluczeniu potomstwa, stwierdzil, iż z faktów przerywania ciąży nie da się wnioskować na zamiary żywione w chwili zawierania małżeństwa.

Trybunał II instancji przesłuchał pozwaną ponownie. Zeznała wtedy, iż po poronieniu postanowiła, iż dzieci więcej mieć nie będzie. Oceniając materiał dowodowy Trybunał zwrócił uwagę na brak spójności w zeznaniach pozwanej i podkreślił, iż „fakty mają silniejszą wymowę niż deklaracje słowne". A fakty te to przerwanie życia każdego poczętego dziecka, niechęć do potomstwa, niezgoda małżeńska spowodowana stanowiskiem pozwanej wobec potomstwa. Trybunał konkluduje: „Przyznanie się pozwanej do odkładania sprawy potomstwa tylko czasowo, lub na innym miejscu na czas nieokreślony, w tym konkretnym przypadku oznacza wykluczenie potomstwa w sposób absolutny, czyli wykluczenie prawa do posiadania potomstwa. To całkowite wykluczenie, odnoszące się początkowo do czasu nieokreślonego (in infinitum), pozwana sprecyzowała wyraźnie w jakimś momencie po ślubie jako nieodwołalne wykluczenie potomstwa $z$ małżeństwa". 
Trybunał III instancji stwierdza jedynie: „Powód dopiero na podstawie przerywania ciąży po ślubie wysuwa wniosek, że pozwana wykluczyła potomstwo. Pozwana zaprzecza tezie powodowej, jakoby wykluczyła posiadanie potomstwa w swoim małżeństwie z powodem". Trybunał III instancji nie ustosunkował się do argumentacji Trybunału II instancji.

2. Wykluczenie potomstwa tak jak ono zostało przyjęte jako podstawa procesu, mieści się w tzw. symulacji małżeńskiej i to symulacji częściowej. Osobie wykluczającej (małżeństwo, jego istotne przymioty lub elementy) zarzuca się wtedy sprzeczność między słowami wypowiadanymi przy zawieraniu małżeństwa a wewnętrzną, rzeczywistą wolą. Udowodnienie takiego zarzutu jest trudne, przedmiotem dowodu jest wszak wewnętrzny akt woli. W orzecznictwie kościelnym przywiązuje się w takich sprawach dużą wage przyznaniu się osoby symulującej, przyczynom symulacji oraz jej okolicznościom. Zeznania osoby, której zarzuca się - całkowitą lub częściową - symulację, wymagają analizy i to nie tylko dla ustalenia ich wiarogodności, lecz także dla wyświetlenia ich sensu. Nie chodzi bowiem o samo stwierdzenie ,symulowałem małżeństwo" (lub ,nie symulowałem"), lecz o faktyczny przedmiot woli w chwili jego zawierania. Zeznania relacjonujące zdarzenia, stany i doznania psychiczne, przeżycia, wyobrażenia i poglądy, trzeba przyporządkować normie k.1101 \$2, by ustalić, czy - w rozpatrywanej sprawie - zarzut wykluczenia potomstwa odpowiada prawdzie.

Ponieważ wyroki poprzednich instancji, opierając się na tym samym materiale dowodowym, różnią się, trzeba wyświetlić prawne podstawy sprawy, czyli: o co chodzi w sprawach o nieważność małżeństwa $z$ tytuhu wykluczenia potomstwa.

Należy najpierw przypomnieć, że nieważność małżeństwa powoduje pozytywny akt woli wykluczajacy czyli akt woli ,przeciw”. Zakłada się zgodność wypowiadanych słów z faktyczną wolą. Zgodność taka nie wymaga pozytywnej afirmacji poszczególnych elementów i przymiotów małżeństwa, do zaistnienia małżeństwa wystarcza gotowość zawarcia małżeństwa zgodnie z prawem (czyli: zgodnie z nauką Kościoła), mówiąc inaczej: gotowość przekazania i przyjęcia praw małżeńskich. Nie jest przeto przedmiotem sprawy pytanie, czy pozwana chciała (lub nie) dzieci, odpowiedź na to pytanie ma charakter jedynie pomocniczy, służący dojściu do odpowiedzi na zasadnicze pytanie procesowe. A to pytanie brzmi: czy pozwana zawierając małżeństwo ograniczyła powoda w prawach, jakie daje małżeństwo. Czyli: czy pozwana pozytywnym 
aktem woli uszczupliła prawa przysługujące powodowi, a wynikające z natury małżeństwa. Wykluczenie potomstwa oznacza zaprzeczenie współmałżonkowi prawa do współdecydowania o potomstwie. Kto zawierając małżeństwo zastrzega wyłącznie sobie prawo decydowania o potomstwie, zawiera je nieważnie, rezerwuje bowiem sobie prawo jednakowo przysługujące obojgu. Zastrzeżenie takie nastepuje aktem wewnętrznym, przy czym skutek tego zastrzeżenia - nieważność małżeństwa - następuje niezależnie od tego, czy nupturient zdawał sobie sprawę z nieważności.

3. Materiał dowodowy należy przeto poddać analizie prowadzacej do odpowiedzi na pytanie, czy pozwana zawierając małżeństwo ograniczyla powoda $w$ jego prawach małżeńskich, konkretnie: w prawach rodzicielskich.

Nie ulega wątpliwości, że pozwana nie wykluczała prawa do współżycia fizycznego. Równie bezsporne jest, że pozwana nie pozwoliła urodzić się poczętej istocie. Pozwana przyznaje też, że drugie przerwanie ciąży nastapiło wbrew prośbom powoda, który usiłował odwieść ją od tego zamiaru. Pozostaje więc pytanie, czy pozwana już z takim postanowieniem szła do ślubu. Za odpowiedzią negatywną przemawiałby fakt, że właśnie z powodu ciąży wyplynęła ,konkretna propozycja zawarcia małżeństwa", pozwana zamiast - jak zamierzała - przerwać ciążę zawarła małżeństwo, a poronienie nastąpiło „,bez żadnej specjalnej przyczyny". W zeznaniach pozwanej sekwencja wydarzeń przedstawia się następująco: zaszła w ciążę, postanowiła ją usunąć, wobec perspektywy zawarcia małżeństwa rezygnuje $z$ tego zamiaru, poronienie następuje samoistnie, następne ciąże zostają przerwane. Faktyczną wolę pozwanej odsłania następująca jej wypowiedź: „Mimo wszystko i wtedy (tj. po usunięciu drugiej ciąży) nie byłam zdecydowana, że absolutnie nigdy nie będą miała dziecka, może kiedyś zdecydowałabym się na donoszenie ciąży".

Ta wypowiedź świadczy, że zrodzenie potomstwa pozwana uzależniała wyłącznie od własnej decyzji, mąż nie miał w tych sprawach nic do powiedzenia: prawo do decydowania o potomstwie zastrzegła wyłącznie sobie. Nie ma znaczenia dla sprawy, jakie byłyby to decyzje, w świetle k.1101 $\$ 2$ istotne jest to, że pozwana wykluczyła powoda $z$ udziału w podejmowaniu decyzji. Właśnie nieustępliwe stanowisko pozwanej co do potomstwa było - jak przyznaje - przyczyną rozejścia się stron, inne przyczyny wysuwano jedynie jako pretekst.

Trybunały I i III instancji koncentrowały się na kwestii, czy pozwana 
„miała zamiar posiadania potomstwa”. Ta kwestia rzeczywiście w świetle jej zeznań pozostaje mglista. Trybunał II instancji orzekł nieważność małżeństwa wykazując, że nastapiło wykluczenie prawa (trzeba jednak zaznaczyć, że nie chodzi o wykluczenie prawa do posiadania potomstwa, gdyż takiego prawa nie ma, lecz o wykluczenie prawa do współdecydowania).

4. Ustalenia Trybunału II instancji doznały wzmocnienia przez zeznania świadków przedstawionych Sądowi ze strony powoda jako „nowe i poważne dowody". Zeznawały siostry powoda, A.P. i T.P. oraz M.T. i T.W. Świadkowie nie wnoszą nowych faktów do sprawy, natomiast charakteryzują sylwetkę pozwanej. ,Wyglądało na to, że to egoistka. Jedynaczka. Rodzice jej nie żyli razem (M.T). „Była wpatrzona w swoją osobę", „to był taki typ niewiasty myślącej o sobie”, , ,egoistyczne nastawienie do życia" - takie wypowiedzi powtarzają się w zeznaniach świadków. Nawet jeśli niektóre sformułowania świadków wydają się zbyt dosadne (,pusta lalka"), to trzeba zauważyć, że już w aktach I instancji znajdują się podobne zeznania świadka nie spokrewnionego z żadną ze stron: „mówiła wyraźnie, że nie będzie mieć dziecka, nawet jeśli wyjdzie za mąż. Nie kryła się $z$ takimi wypowiedziami, chciała być swobodna, lubiła wyjeżdżać za granicę, więc uważała, że dziecko skomplikowałoby jej życie". Te zeznania pokazują psychologiczne tho faktycznego zarezerwowania sobie przez pozwana prawa do decydowania o potomstwie.

Biorąc powyższe pod uwagę Sąd Metropolitalny daje twierdzącą odpowiedź na pytanie procesowe i stwierdza, iż udowodniono nieważność małżeństwa $z$ tytułu wykluczenia potomstwa przez pozwana. Tym samym Sąd uchyla - odnośnie do tego tytułu nieważności - wyrok Trybunału III instancji. 